\title{
Supplemental epilactose prevents metabolic disorders through uncoupling protein-1 induction in the skeletal muscle of mice fed high-fat diets
}

\author{
Yuki Murakami ${ }^{1}$, Teruyo Ojima-Kato ${ }^{2}$, Wataru Saburi ${ }^{3}$, Haruhide Mori $^{3}$, Hirokazu Matsui ${ }^{3}$, \\ Soichi Tanabe ${ }^{1}$ and Takuya Suzuki ${ }^{1 *}$ \\ ${ }^{1}$ Department of Biofunctional Science and Technology, Graduate School of Biosphere Science, Hiroshima University, \\ Higashi-Hiroshima 739-8528, Japan \\ ${ }^{2}$ Department of Bioengineering Sciences, Graduate School of Bioagricultural Sciences, Nagoya University, Nagoya 464-8601, Japan \\ ${ }^{3}$ Division of Applied Bioscience, Research Faculty of Agriculture, Hokkaido University, Sapporo 060-8589, Japan
}

(Submitted 21 May 2015 - Final revision received 30 July 2015 - Accepted 11 August 2015 - First published online 23 September 2015)

\begin{abstract}
Obesity is one of the major health problems throughout the world. The present study investigated the preventive effect of epilactose - a rare non-digestible disaccharide - on obesity and metabolic disorders in mice fed high-fat (HF) diets. Feeding with HF diets increased body weight gain, fat pad weight and adipocyte size in mice $(P<0 \cdot 01)$, and these increases were effectively prevented by the use of supplemental epilactose without influencing food intake $(P<0 \cdot 01)$. Caecal pools of SCFA such as acetic and propionic acids in mice fed epilactose were higher compared with mice not receiving epilactose. Supplemental epilactose increased the expression of uncoupling protein (UCP)-1, which enhances energy expenditure, to 2 -fold in the gastrocnemius muscle $(P=0.04)$ and to 1.3 -fold in the brown adipose tissue $(P=0 \cdot 02)$ in mice fed HF diets. Feeding HF diets induced pro-inflammatory macrophage infiltration into white adipose tissue, as indicated by the increased expression of monocyte chemotactic protein-1, TNF- $\alpha$ and $F 4 / 80$, and these increases were attenuated by supplemental epilactose. In differentiated myogenic-like $\mathrm{C} 2 \mathrm{C} 12$ cells, propionic acid, but not acetic or $n$-butyric acids, directly enhanced $U C P-1$ expression by approximately 2 -fold $(P<0 \cdot 01)$. Taken together, these findings indicate that the epilactose-mediated increase in $U C P-1$ in the skeletal muscle and brown adipose tissue can enhance whole-body energy expenditure, leading to effective prevention of obesity and metabolic disorders in mice fed HF diets. It is suggested that propionic acid - a bacterial metabolite - acts as a mediator to induce UCP-1 expression in skeletal muscles.
\end{abstract}

\section{Key words: Epilactose: Propionic acid: Obesity: Uncoupling protein: Skeletal muscle}

Non-digestible carbohydrates such as dietary fibres and oligosaccharides have a variety of beneficial effects on our health. Epilactose (4-O- $\beta$-galactopyranosyl-D-mannose) is a rare nondigestible disaccharide, which can be produced in considerable amounts by heating and alkali treatment of cows' milk ${ }^{(1)}$. Recently, we have developed a method for the mass-production of epilactose using cellobiose 2-epimerase (EC 5.1.3.11) from the ruminal strain Ruminococcus albus $\mathrm{NE}^{(2)}$. Although our previous studies have found that epilactose enhances the absorption of intestinal $\mathrm{Ca}$ and $\mathrm{Fe}$ in rodents ${ }^{(3)}$, information on its biological functions remains quite limited. As previous studies have demonstrated that some non-digestible carbohydrates ameliorate metabolic disorders such as obesity, epilactose also may have a potential to prevent these disorders.

Obesity and related diseases, such as diabetes and CVD, have emerged as major health problems in many countries, particularly in the West ${ }^{(4)}$. It is known that obesity and diabetes are the results of a complex interaction between genetic and environmental factors. In particular, the intake of a fat-enriched diet and intake of excessive calories are primary factors associated with the increased occurrence and further progression of metabolic disorders. At the same time, the consumption of cereals, a major source of non-digestible carbohydrates, is falling in Western countries, and a number of important relationships between the intestinal fermentation of these carbohydrates and the regulation of metabolic disorders have been suggested ${ }^{(5-7)}$. It appears that the release of bacterial metabolites - that is, SCFA including acetic, propionic and butyric acids - plays a number of important roles in metabolic regulation. Previous studies have shown that luminal SCFA change the synthesis of gastrointestinal peptides such as peptide YY and glucagon-like peptide-1, which control food intake and glucose tolerance ${ }^{(8,9)}$. In addition, the SCFA transported to the circulatory system reportedly act as regulators of energy metabolism and adiposity ${ }^{(10,11)}$. However, the precise roles of SCFA in the regulation of metabolic disorders and energy metabolisms remain to be clarified.

Energy metabolism is organised by different systems or mechanisms in mammals. The uncoupling protein (UCP) is

Abbreviations: C, control; Epi, epilactose; HF, high fat; MCP-1, monocyte chemotactic protein; Std, standard diet; UCP-1, uncoupling protein-1.

* Corresponding author: T. Suzuki, fax +81 82424 7916, email takuya@hiroshima-u.ac.jp 
located in the mitochondrial inner membrane, where it uncouples the oxidation of fuels, mainly fatty acids, from ATP production, so that the energy associated with fuel oxidation is simply released as heat. $U C P-1$ is highly expressed in brown adipose tissue, which specialises in the production of heat through non-shivering thermogenesis ${ }^{(12)}$. Therefore, UCP-1 activation could serve as a novel therapeutic approach for the treatment of obesity. In addition, recent studies have demonstrated that the ectopic expression of $U C P-1$ in the skeletal muscle of mice increases whole-body energy expenditure, resulting in the restoration of insulinaemia, cholestelolaemia and adiposity $^{(13,14)}$. Although the basal density of $U C P-1$ in skeletal muscle is lower than that in brown adipose tissue, evidence suggests that increased $U C P-1$ in skeletal muscle could make a significant contribution to whole-body energy expenditure due to the large muscle mass.

The purpose of present study was to investigate the preventive effect of epilactose on obesity and metabolic dysregulation in mice fed high-fat (HF) diets in relation to intestinal fermentation. Further, the direct effects of SCFA on UCP-1 expression in differentiated myogenic-like cells were also examined.

\section{Methods}

\section{Animals (Expt 1 and 2)}

All animal studies were pre-approved by the Hiroshima University Animal Committee, and the mice were maintained in accordance with the Hiroshima University guidelines for the care and use of laboratory animals (no. C11-24).

Male C57/BL6 mice ( 5 weeks old; Charles River) were housed in cages in a room with controlled temperature $\left(22(\operatorname{sem} 2)^{\circ} \mathrm{C}\right)$, relative humidity (40-60\%) and lighting (light 08.00-20.00 hours) throughout the study. The body weight and food intake of the mice were measured every day. The mice were allowed to acclimatise to the laboratory environment with free access to the control diet (AIN-93G formula; Table 1) $)^{(15)}$ and distilled water for 1 week.

In Expt 1, mice were randomly divided into the following four groups; the standard diet (Std)-control (Cont), Std-epilactose (Epi), HF-Cont and HF-Epi groups ( $n 7-8$ per group). The Std-Epi and Std-Cont groups were fed a diet containing $7 \%$ soyabean oil with and without $10 \%$ epilactose by weight (Table 1 ). The HF-Epi and HF-Cont groups were fed diets containing $7 \%$ soyabean oil and $33 \%$ lard with and without $10 \%$ epilactose. Epilactose was added to the experimental diets by substitution for an equal amount of starch. The mice had free access to each experimental diet for 8 weeks. On day 54 of the experimental period, mice were fasted for $8 \mathrm{~h}$, and blood samples were collected from the tail vein to measure plasma glucose, insulin and TAG levels. At the end of the experiment, the mice were sacrificed by exsanguination under diethyl ether anaesthesia. The livers and fat pads (mesenteric, epididymal and retroperitoneal) were removed and weighed, and the epididymal fat pads were fixed with $4 \%$ paraformaldehyde and embedded in paraffin for haematoxylin-eosin staining. Adipocyte size was determined by averaging the diameters of at least fifty adipocytes from the fat pad of each mice.
Table 1. Composition of diets (Expt 1 and 2)

\begin{tabular}{lcc}
\hline Ingredient & Standard diet $(\mathrm{g} / \mathrm{kg} \text { diet })^{*}$ & ${\text { High-fat diet }(\mathrm{g} / \mathrm{kg} \mathrm{diet})^{*}}^{*}$ \\
\hline Maize starch $\dagger$ & 429.5 & 199.5 \\
Sucrose & 100 & 100 \\
Casein $\ddagger$ & 200 & 200 \\
Soyabean oil & 70 & 70 \\
Lard & 0 & 330 \\
Cellulose§ & 50 & 50 \\
Mineral mix\| & 35 & 35 \\
Vitamin mix\|l & 10 & 10 \\
L-Cystine & 3 & 3 \\
Choline bitartrate & 2.5 & 2.5 \\
\hline
\end{tabular}

* Epilactose was added to diets at $10 \%$ through substitution of an equal amount of maize starch.

† Maize starch (a-maize starch; Chuou Shokuryo Co. Ltd).

$\ddagger$ Casein (ALACID; New Zealand Daily Board).

$\S$ Crystallised cellulose (Ceolus PH102; Asahi Chemical Industry).

II Mineral and vitamin mixtures were prepared according to the AIN-93G formulation.

The caecal contents were also collected for organic acid analyses as described below.

In Expt 2, mice were randomly divided into the following three groups: the Std-Cont, HF-Cont and HF-Epi groups ( $n$ 7-8 per group). Experimental diets and periods were the same as those in Expt 1. To evaluate the effects of epilactose on lipid absorption and excretion, faeces samples were collected continuously for $3 \mathrm{~d}$ from day 51 after the start of feeding the test diets. At the end of the experiment, the liver, fat pads, gastrocnemius muscle and suprascapular brown adipose tissue were collected and weighed for quantitative RT-PCR analysis as described below.

\section{Measurements of plasma glucose, insulin and TAG}

The plasma glucose and TAG concentrations were assayed by enzymatic methods using commercially available kits (Glucose CII and TAG E Test Wako; Wako Pure Chemical Industries). The plasma insulin concentration was assayed using an ELISA kit (Ultra Sensitive Mouse Insulin ELISA Kit; Morinaga Institute of Biological Science).

\section{Organic acid analysis}

The caecal contents were diluted with four volumes of distilled water and homogenised using a polytron-type homogeniser. A $5 \mu \mathrm{l}$ of $25 \mathrm{~mm}$ crotonic acid as an internal standard was added to $70 \mu \mathrm{l}$ of caecal contents and the mixture was centrifuged at $15700 \mathrm{~g}$ for $10 \mathrm{~min}$ at $4^{\circ} \mathrm{C}$. The resultant supernatant was de-proteinised with $1 \%$ sulphosalicylic acid and diluted with two volumes of distilled water. The samples were filtrated and applied to a UPLC/MS system.

Organic acids (acetic, propionic, $n$-butyric, iso-butyric, $n$-valeric, iso-valeric, lactic, succinic and crotonic acids) were identified and quantified using a UPLC/MS system equipped with an electric spray ionisation (ESI) interface (Acquity UPLC; Waters Co. Ltd). The temperature of the capillary heater and vaporisation heater was maintained at 120 and $400^{\circ} \mathrm{C}$, respectively. The flow rate of the sheath gas (N) was $150 \mathrm{l} / \mathrm{h}$. LC/ESI-MS was carried out in scan mode from $(\mathrm{m} / \mathrm{z})+50$ to 2000 and in selected 
ion recording (SIR) mode from $(\mathrm{m} / \mathrm{z})+59 \cdot 0$ for acetic acid, $(\mathrm{m} / \mathrm{z})+73.0$ for propionic acid, $(\mathrm{m} / \mathrm{z})+87 \cdot 0$ for $n$ - and iso-butyric acid, $(\mathrm{m} / \mathrm{z}) 101 \cdot 1$ for $n$ - and iso-valeric acid, $(\mathrm{m} / \mathrm{z})$ $89 \cdot 0$ for lactic acid, $(\mathrm{m} / \mathrm{z}) \quad 117 \cdot 0$ for succinic acid and $(\mathrm{m} / \mathrm{z}) 85 \cdot 1$ for crotonic acid. The UPLC system was fitted with a $1.8 \mu \mathrm{m} \mathrm{C} 18$ column (ACQUITY UPLC HSS T3, 2.1×100 mm; Waters Co. Ltd) set at $40^{\circ} \mathrm{C}$. Solvents A (water-formic acid, 100:0·1) and B (methanol-formic acid, 100:0.1) were run at a flow rate of $0.2 \mathrm{ml} / \mathrm{min}$ using a gradient from 0 up to $5 \%$ solvent $\mathrm{B}$ for $2 \mathrm{~min}$, followed by $0 \%$ solvent B for $2 \mathrm{~min}$, from 5 up to $60 \%$ solvent B for $8 \mathrm{~min}$, from 60 up to $80 \%$ solvent B for $1 \mathrm{~min}$ and from 80 up to $10 \%$ solvent $\mathrm{B}$ for $2 \mathrm{~min}$ and then reduced linearly back to $0 \%$ solvent $\mathrm{B}$ over the next $1 \mathrm{~min}$ and subsequently maintained at the initial condition for $5 \mathrm{~min}$. The injection volume was $5 \mu \mathrm{l}$. Concentrations of individual organic acids were calculated from the peak area in the chromatogram detected with SIR relative to the internal standard (crotonic acid)

\section{Measurement of faecal TAG}

Faeces samples collected in Expt 2 were freeze-dried and milled. Total lipids were extracted from powdered faeces (about $100 \mathrm{mg}$ ) using the Bligh \& Dyer method ${ }^{(16)}$. TAG levels in the extracts were estimated by an enzymatic method as described above.

\section{Quantitative RT-PCR analysis}

Total RNA from the mouse tissues and $\mathrm{C} 2 \mathrm{C} 12$ cells were isolated using TRI reagent (Sigma) and reverse-transcribed using a ReverTra Ace qPCR RT kit (TOYOBO) according to the manufacturer's instructions. Real-time qPCR was performed using a Step One Real-Time PCR system (Life Technologies) and a KAPA SYBR FAST qPCR kit (KAPA BIOSYSTEMS). The primer sequences used for the PCR are shown in online Supplementary Table S1. Data were analysed by the $\Delta \Delta C_{t}$ method and presented as fold changes in gene expression after normalisation to the internal control (GAPDH gene expression level).

\section{Immunoblot analysis}

Mouse tissues $(50 \mathrm{mg}$ ) were homogenised in $1 \mathrm{ml}$ lysis buffer containing $1 \%(\mathrm{w} / \mathrm{v})$ SDS, $1 \%(\mathrm{v} / \mathrm{v})$ TritonX-100 and $1 \%(\mathrm{w} / \mathrm{v})$ sodium deoxycholate in $30 \mathrm{mmol} / \mathrm{l}$-Tris with protease and phosphatase inhibitors ( $\mathrm{pH} 7.4$ ) using a polytron-type homogeniser. Protein concentrations were measured using the BCA method (Pierce Biotechnology). Tissue extracts were mixed with a half volume of Laemmli sample buffer ( $3 \times$ concentrated) containing $6 \%(\mathrm{w} / \mathrm{v})$ SDS, 30\% $(\mathrm{v} / \mathrm{v})$ glycerol, $15 \%(\mathrm{v} / \mathrm{v})$ 2 - $\beta$-mercaptoethanol and $0.02 \%(\mathrm{w} / \mathrm{v})$ bromphenol blue in $188 \mathrm{mmol} / \mathrm{l}$-Tris, (pH 6.8) and heated to $100^{\circ} \mathrm{C}$ for $5 \mathrm{~min}^{(17)}$. Proteins $(30 \mu \mathrm{g})$ were separated by SDS-PAGE and transferred to PVDF membranes. Membranes were blotted for $U C P-1$ and $\beta$-actin using specific antibodies in combination with HRP-conjugated anti-mouse or anti-rabbit IgG antibodies. The blots were developed using the ECL chemiluminescence method (Perkin Elmer). Quantification was performed by densitometric analysis of specific bands on the immunoblots using Image J software.

\section{Cell culture (Expt 3)}

To examine the direct effects of organic acids on UCP-1 expression in the skeletal muscle, a mouse myoblastic-like C2C12 cell line was used. C2C12 cells (CRL-1772; American Type Culture Collection) were propagated and maintained using DMEM supplemented with $10 \%$ FBS as described previously ${ }^{(18)}$. The cells were seeded into twenty-four-well plates $\left(1.9 \mathrm{~cm}^{2}\right.$; Thermo Scientific Inc.) at a density of $0 \cdot 44 \times 10^{5}$ cells $/ \mathrm{cm}^{2}$. After the cells reached confluence, the medium was replaced with myogenic medium consisting of DMEM supplemented with $2 \%$ horse serum to induce myogenic differentiation. All the experiments were conducted on day 8 after the start of differentiation. Cultures were used between passage 7 and 11, and the medium was refreshed every $2 \mathrm{~d}$. The experiment was repeated three times, and a representative analysis is shown in the result section.

Three individual organic acids - acetic, propionic and $n$-butyric acids - were administered into the medium (0.3-3.0 mm-acetic acid, 0.1-1.0 mm-propionic acid and $0 \cdot 01-0 \cdot 1 \mathrm{~mm}-n$-butyric acid). These concentrations were chosen based on the physiological levels present in the blood of rodents ${ }^{(19)}$. The total RNA and protein contents of cells incubated with organic acids for $24 \mathrm{~h}$ were determined to examine the $U C P-1$ gene and protein expressions as described above.

\section{Statistical analysis}

All the values are expressed as means with their standard errors. The significance of differences between groups was assessed using the Tukey-Kramer post hoc test. A difference with a $P$ value $<0.05$ was considered significant. Statistical analyses were performed using JMP software (version 12; SAS Institute Inc.).

\section{Results \\ Feeding epilactose prevents high-fat-diet-induced metabolic disorders (Expt 1)}

Feeding HF diets induced increases in body weight and the weight of the three fat pads (epididymal, retroperitoneal and mesenteric adipose tissues, Tables 2 and 3). The body weight gain and total fat pad weights were increased approximately 1.6-fold by HF diets $(P<0 \cdot 01)$. Supplemental feeding with epilactose effectively prevented these increases, and the body weight gain and individual fat pad weights in the HF-Epi group were lower than those in the HF-Cont group $(P<0 \cdot 01)$ without any difference in the food intake between the two groups. There were no differences in liver weight among the four groups. Feeding epilactose did not have any effect on these parameters in mice fed the standard diets.

Plasma glucose, insulin and TAG concentrations in mice were measured to examine metabolic dysregulation (Table 4). Although no differences were detected in the plasma glucose concentration among the groups, the HF diets increased plasma 
Table 2. Body weight, food intake and caecum weight of mice (Expt 1)

(Mean values with their standard errors; $n$ 7-8)

\begin{tabular}{|c|c|c|c|c|c|c|c|c|}
\hline \multirow[b]{2}{*}{ Diet } & \multicolumn{2}{|c|}{ Body weight gain (g/8 weeks) } & \multicolumn{2}{|c|}{ Food intake ( $g / 8$ weeks) } & \multicolumn{2}{|c|}{ Caecum tissue (mg/ $1 \mathrm{~g}$ body weight) } & \multicolumn{2}{|c|}{ Caecum content (mg) } \\
\hline & Mean & SEM & Mean & SEM & Mean & SEM & Mean & SEM \\
\hline \multicolumn{9}{|l|}{ Standard } \\
\hline Control & $7 \cdot 6^{\mathrm{b}}$ & 0.2 & $171^{\mathrm{a}}$ & 7 & $2.57^{\mathrm{b}}$ & 0.10 & $94.5^{\mathrm{c}}$ & 9.0 \\
\hline Epilactose & $7.8^{\mathrm{b}}$ & 0.6 & $165^{\mathrm{a}}$ & 5 & $5 \cdot 21^{a}$ & 0.24 & $370^{\mathrm{a}}$ & 37 \\
\hline \multicolumn{9}{|l|}{ High fat } \\
\hline Control & $12 \cdot 3^{\mathrm{a}}$ & 0.6 & $152^{\mathrm{b}}$ & 4 & $1.76^{b}$ & 0.10 & $99.8^{\mathrm{C}}$ & $7 \cdot 1$ \\
\hline Epilactose & $8.0^{b}$ & 0.8 & $149^{\mathrm{b}}$ & 5 & $4 \cdot 48^{\mathrm{a}}$ & 0.34 & $236^{\mathrm{b}}$ & 33 \\
\hline
\end{tabular}

${ }^{\mathrm{a}, \mathrm{b}, \mathrm{c}}$ Mean values with unlike superscript letters were significantly different $(P<0.05)$.

Table 3. Liver and white adipose tissue weights (Expt 1)

(Mean values with their standard errors; $n 7-8$ )

\begin{tabular}{|c|c|c|c|c|c|c|c|c|}
\hline \multirow[b]{3}{*}{ Diet } & & & \multicolumn{6}{|c|}{ White adipose tissue (mg/1 g body weight) } \\
\hline & \multicolumn{2}{|c|}{ Liver (mg/1 g body weight) } & \multicolumn{2}{|c|}{ Epididymal } & \multicolumn{2}{|c|}{ Retroperitoneal } & \multicolumn{2}{|c|}{ Mesenteric } \\
\hline & Mean & SEM & Mean & SEM & Mean & SEM & Mean & SEM \\
\hline \multicolumn{9}{|l|}{ Standard } \\
\hline Control & 37.4 & 0.9 & $32 \cdot 4^{\mathrm{b}}$ & 2.5 & $12 \cdot 9^{\mathrm{b}}$ & 0.9 & $9 \cdot 7^{\mathrm{b}}$ & 0.7 \\
\hline Epilactose & 37.6 & 0.7 & $32 \cdot 0^{\mathrm{b}}$ & $2 \cdot 0$ & $11 \cdot 4^{\mathrm{b}}$ & 1.3 & $9 \cdot 1^{\mathrm{b}}$ & 0.4 \\
\hline \multicolumn{9}{|l|}{ High fat } \\
\hline Control & 33.2 & 1.3 & $58 \cdot 1^{a}$ & $2 \cdot 3$ & $19 \cdot 9^{a}$ & 0.6 & $12 \cdot 5^{\mathrm{a}}$ & 0.5 \\
\hline Epilactose & 34.9 & 1.2 & $36 \cdot 1^{\mathrm{b}}$ & 3.4 & $11 \cdot 6^{\mathrm{b}}$ & 1.0 & $8 \cdot 2^{\mathrm{b}}$ & 0.5 \\
\hline
\end{tabular}

${ }^{\mathrm{a}, \mathrm{b}}$ Mean values with unlike superscript letters were significantly different $(P<0.05)$

Table 4. Plasma glucose, insulin, TAG and Homoeostasis model assessment for insulin resistance (HOMA-IR) in fasted mice (Expt 1)

(Mean values with their standard errors; $n$ 7-8)

\begin{tabular}{|c|c|c|c|c|c|c|c|c|}
\hline \multirow[b]{2}{*}{ Diet } & \multicolumn{2}{|c|}{ Glucose (mм) } & \multicolumn{2}{|c|}{ Insulin (ng/ml) } & \multicolumn{2}{|c|}{ TAG (mm) } & \multicolumn{2}{|c|}{ HOMA-IR } \\
\hline & Mean & SEM & Mean & SEM & Mean & SEM & Mean & SEM \\
\hline \multicolumn{9}{|l|}{ Standard } \\
\hline Control & $14 \cdot 8$ & 0.4 & $1.07^{a, b}$ & 0.13 & $0.97^{a}$ & 0.04 & $13 \cdot 8^{b}$ & $1 \cdot 2$ \\
\hline Epilactose & $14 \cdot 3$ & 0.3 & $0.81^{b}$ & 0.01 & $0.86^{a, b}$ & 0.03 & $12 \cdot 4^{b}$ & 1.5 \\
\hline \multicolumn{9}{|l|}{ High fat } \\
\hline Control & $15 \cdot 0$ & 0.6 & $1 \cdot 41^{\mathrm{a}}$ & 0.12 & $0.86^{a, b}$ & 0.02 & $23 \cdot 3^{a}$ & $2 \cdot 1$ \\
\hline Epilactose & $13 \cdot 3$ & 0.8 & $0.77^{\mathrm{b}}$ & 0.08 & $0.74^{b}$ & 0.03 & $11 \cdot 1^{b}$ & 1.6 \\
\hline
\end{tabular}

a,b Mean values with unlike superscript letters were significantly different $(P<0.05)$

insulin concentrations to $1 \cdot 3$-fold $(P<0 \cdot 01)$, and this increase was attenuated by feeding epilactose $(P<0 \cdot 01)$. Homoeostasis model assessment for insulin resistance, an indicator of insulin resistance, in the HF-Cont group was nearly double than that in mice fed the standard diets $(P<0 \cdot 01)$, but the HF-Epi group showed a marked increase in value similar to those of the Std-Cont and Std-Epi groups. Plasma TAG concentrations in the Std-Epi and HF-Cont groups tended to be lower than that in the Std-Cont group, and TAG concentrations in the HF-Epi group was $24 \%$ lower than that in the Std-Cont group $(P<0 \cdot 01)$.

Haematoxylin-eosin staining of the epididymal fat pads showed that feeding HF diets led to hypertrophy of the adipocytes, indicating excessive fat accumulation in the cells (Fig. 1). The morphology of adipocytes in the HF-Epi group was observed to be similar to those in the two standard diet groups. The average diameter of adipocytes in the HF-Epi group was approximately $30 \%$ lower than that in the HF-Cont group $(P=0.03)$.

\section{Feeding epilactose leads to the accumulation of organic acid pools in the caecum (Expt 1)}

Intestinal bacterial metabolites in the form of organic acids were determined in the caecum, as epilactose is known to exhibit a prebiotic property. The levels of all organic acids measured, except for lactic and succinic acids, were higher in the Std-Epi group compared with the Std-Cont group (Fig. 2). Acetic, propionic, $n$-valeric and iso-valeric acid levels in the HF-Epi group were 3- to 6-fold higher compared with the HF-Cont group $(P<0 \cdot 01)$. Incremental trends were observed for succinic, $n$-butyric and iso-butyric acids by the supplemental feeding of epilactose in mice fed the HF diets. 
(A)
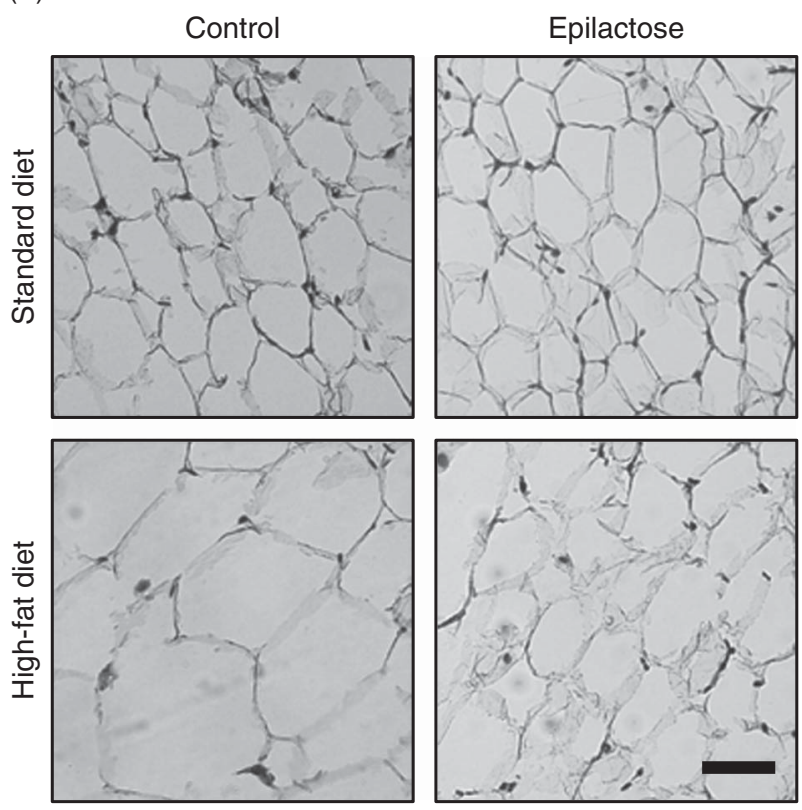

(B)

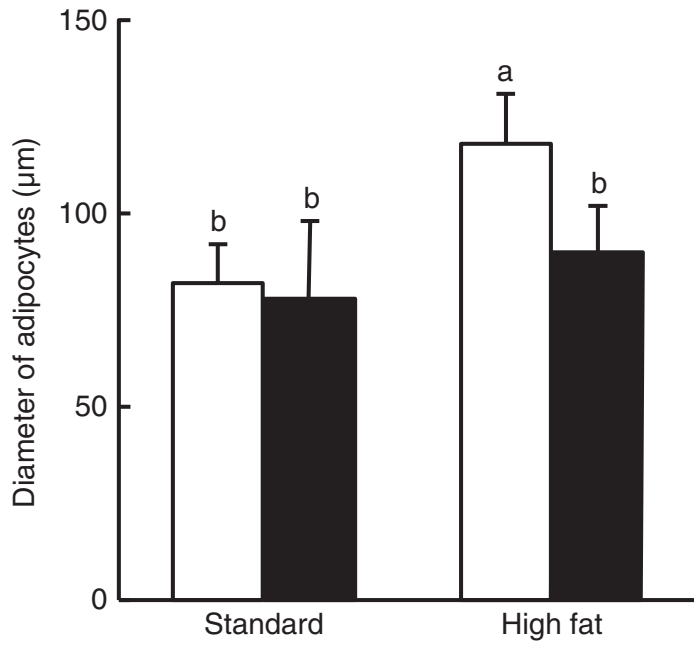

Fig. 1. Haematoxylin-eosin staining images and adipocyte diameters of the epididymal adipose tissue of mice in Expt 1. (A) Representative haematoxylineosin staining images of epididymal adipose tissue of mice are shown. A black bar indicates $100 \mu \mathrm{m}$. (B) Quantification of adipocyte diameters is shown. Values are means ( $n 7-8)$, with their standard errors represented by vertical bars. ${ }^{a, b}$ Mean values with unlike letters were significantly different $(P<0.05)$. $\square$, Control; $\square$, Epilactose.

Feeding epilactose enhanced uncoupling protein-1 expression in skeletal muscle and brown adipose tissue (Expt 2)

To investigate the mechanisms underlying the epilactosemediated prevention of HF diet-induced metabolic disorders, another animal study using three experimental groups (Std-Cont, HF-Cont and HF-Epi groups) was conducted, and the expression levels of genes involved in carbohydrate and lipid metabolisms together with energy expenditure in the liver, white adipose tissue, skeletal muscles and brown adipose tissue, were examined. Feeding the HF diet increased the body weight and fat pad weights in mice $(P<0 \cdot 01)$, whereas supplemental feeding with epilactose prevented these increases in a similar manner to the results observed in Expt $1(P<0 \cdot 01$, Table 5). No differences were observed in gastrocnemius muscle or suprascapular brown adipose tissue weights among the groups.

The expression levels of two genes involved in fatty acid synthesis - fatty acid synthase (FAS) and acetyl-CoA carboxylase- $\alpha$ - were approximately 60 and $40 \%$ lower in the livers of the HF-Cont and HF-Epi groups than in those of the Std-Cont group $(P<0 \cdot 01$, Fig. 3). Gluconeogenesis-related genes - phosphoenolpyruvate carboxykinase 1 and glucose6-phosphatase - were increased 2- and 3-fold, respectively, by feeding the HF diets $(P<0 \cdot 01)$. Expressions of these genes in the liver were not influenced by epilactose. In the pathogenesis of metabolic syndrome and obesity, macrophages are chemoattracted by the monocyte chemotactic protein (MCP)-1 to adipocytes, leading to inflammation. Although no differences in lipoprotein lipase, hormone-sensitive lipase and $P P A R \gamma$ gene expression levels were found among the groups, the inflammation markers, MCP-1 $(P<0.01)$, TNF- $\alpha(P<0 \cdot 01)$ and $F 4 / 80$ expression levels $(P=0.04)$, were increased 1.5 - to $2 \cdot 5$-fold by feeding the HF diets (Fig. 4). Supplemental feeding with epilactose prevented the increases in $M C P-1(P<0 \cdot 01)$ and $T N F-\alpha$ expression $(P<0 \cdot 01)$ and tended to attenuate the increase in F4/80. In addition, UCP-1, Cidea and PPAR $\gamma$ coactivator $1 \alpha$ $(P G C-1 \alpha)$ expressions in white adipose tissues were examined, because recent studies have shown that another $U C P$-1-positive cell, referred to as a beige adipocyte, resides in white adipose tissues and contributes to the energy expenditure. However, no difference was observed in these two gene expressions in white adipose tissues (data not shown). Among the genes examined in the gastrocnemius muscle, the expression of $U C P-1$, which is involved in the dissipation of energy as heat, thereby enhancing energy expenditure, was influenced by diet (Fig. 5), with UCP-1 expression in the HF-Epi group being more than double compared with the other groups at the mRNA and protein levels $(P=0.04)$. The brown adipose tissue specialises in generating heat through non-shivering thermogenesis using UCP proteins. $U C P-1$ mRNA and protein expressions in the two HF diet groups were higher than that in the Std-Cont group $(P<0.01$ and $P=0.03)$, and these $U C P-1$ expressions in the HF-Epi group were even higher than that in the HF-Cont group (Fig. 6). The $U C P-1$ expressions in the HF-Epi groups were approximately $25 \%$ higher than those in the HF-Cont groups at the mRNA and protein levels $(P=0.02$ and 0.03$)$. The expression of $P G C-1 \alpha$, a regulator of $U C P-1$ transcription, in the HF-Epi group was $50 \%$ higher compared with the expression levels in the other groups $(P=0.04)$.

Faecal excretions of TAG were higher in the two HF groups than in the Std-Cont group $(P<0 \cdot 01)$, but feeding epilactose did not influence excretion (Std-Cont, 0.58 (sem 0.06); HF-Cont, $2 \cdot 16$

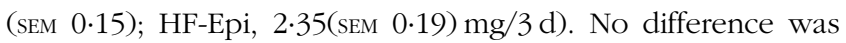
observed in dry weights of faeces collected for $3 \mathrm{~d}$ among groups.

Propionic acid induces uncoupling protein-1 expression in differentiated C2C12 cells

C2C12 cells were used to examine the direct effects of three major organic acids - acetic, propionic and $n$-butyric 
(A)
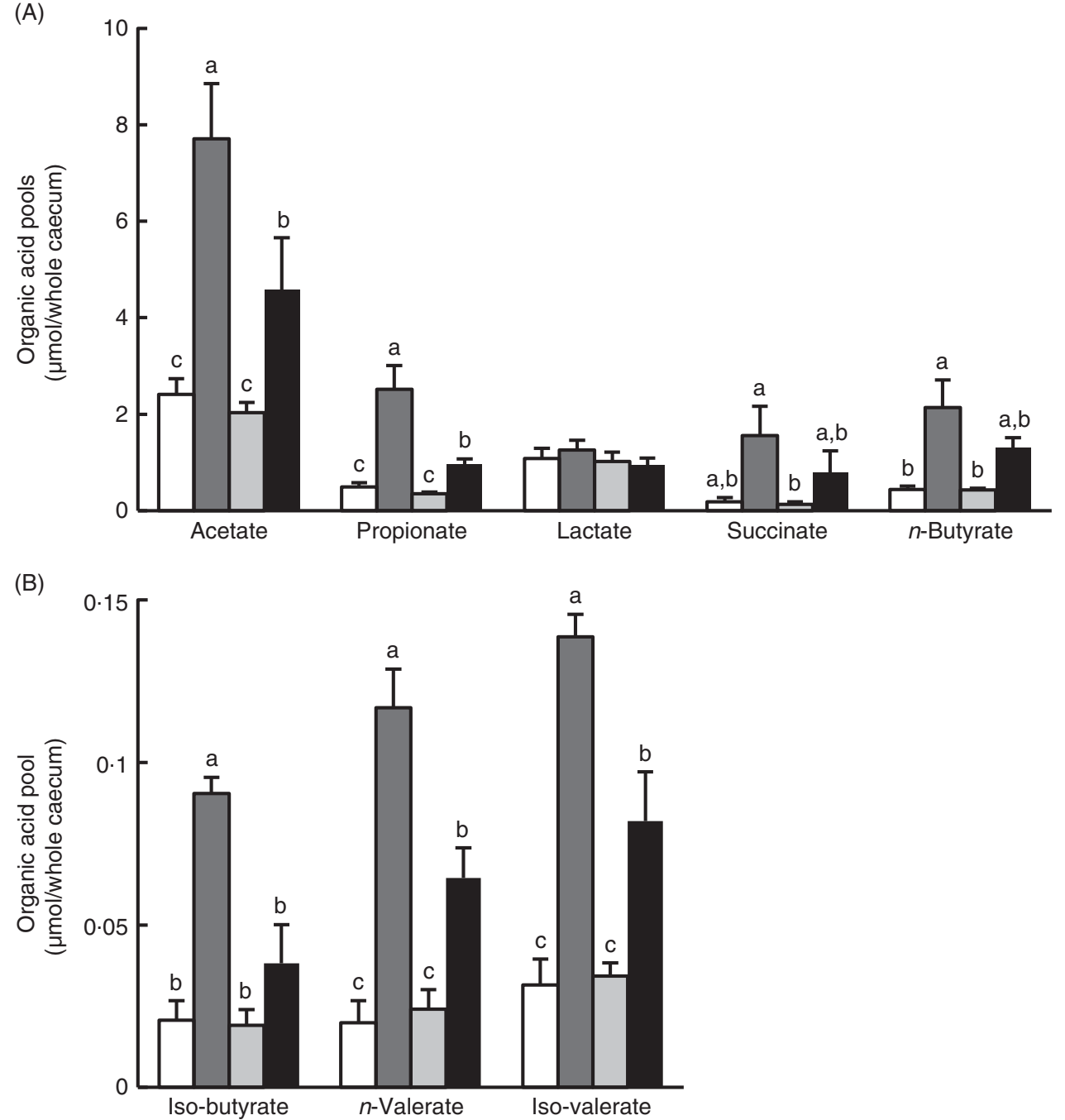

Fig. 2. Organic acid pools in the caecum of mice in Expt 1. Caecum samples were collected at the end of experiment. (A) Pools of acetate, propionate, lactate, succinate and $n$-butyrate are shown. (B) Pools of iso-butyrate, $n$-valerate and iso-valerate are shown. Std, standard diet; HF, high-fat diet; Cont, control; Epi, epilactose. Values are means $\left(n\right.$ 7-8), with their standard errors represented by vertical bars. ${ }^{\mathrm{a}, \mathrm{b}, \mathrm{c}}$ Mean values with unlike letters were significantly different $(P<0.05)$. $\square$, Std-Cont; $\square$, Std-Epi; $\square$, HF-Cont; $\square$, HF-Epi.

Table 5. Body weight gain, food intake and white adipose tissue, brown adipose tissue and gastrocnemius muscle weights (Expt 2) (Mean values with their standard errors; $n$ 7-8)

\begin{tabular}{|c|c|c|c|c|c|c|c|c|c|c|}
\hline \multirow[b]{2}{*}{ Diet } & \multicolumn{2}{|c|}{$\begin{array}{l}\text { Body weight gain } \\
\text { (g/8 weeks) }\end{array}$} & \multicolumn{2}{|c|}{$\begin{array}{l}\text { Food intake } \\
\text { (g/8 weeks) }\end{array}$} & \multicolumn{2}{|c|}{$\begin{array}{l}\text { White adipose tissue } \\
\text { (mg/1 g body weight) }\end{array}$} & \multicolumn{2}{|c|}{$\begin{array}{l}\text { Brown adipose tissue } \\
\text { (mg/1 g body weight) }\end{array}$} & \multicolumn{2}{|c|}{$\begin{array}{l}\text { Gastrocnemius muscle } \\
\text { (mg/1 g body weight) }\end{array}$} \\
\hline & Mean & SEM & Mean & SEM & Mean & SEM & Mean & SEM & Mean & SEM \\
\hline \multicolumn{11}{|l|}{ Standard } \\
\hline Control & $8 \cdot 9^{b}$ & 0.6 & $174^{a}$ & 6 & $67 \cdot 4^{b}$ & 3.7 & 3.6 & 0.2 & $4 \cdot 7$ & 0.2 \\
\hline \multicolumn{11}{|l|}{ High fat } \\
\hline Control & $12 \cdot 6^{a}$ & $1 \cdot 1$ & $151^{b}$ & 4 & $90 \cdot 2^{a}$ & $6 \cdot 7$ & 3.9 & 0.2 & 4.6 & 0.2 \\
\hline Epilactose & $8 \cdot 5^{\mathrm{b}}$ & 0.9 & $144^{\mathrm{b}}$ & 2 & $62 \cdot 6^{b}$ & $7 \cdot 7$ & 3.6 & 0.2 & $5 \cdot 2$ & 0.2 \\
\hline
\end{tabular}

${ }^{\mathrm{a}, \mathrm{b}}$ Mean values with unlike superscript letters were significantly different $(P<0.05)$.

acids - on $U C P-1$ expression. The cells incubated with $0 \cdot 1$ and $0.3 \mathrm{~mm}$-propionic acid showed dose-dependent increases in $U C P-1$ mRNA expression $(P=0.03$ and $P<0 \cdot 01$, Fig. 7). Similarly, the $U C P-1$ protein expressions were increased by $0 \cdot 1$ and
0.3 mm-propionic acids $(P<0 \cdot 01)$. No significant effect were observed after incubation with acetic and $n$-butyric acids, although an incremental trend was observed in the cells incubated with 0.1 mu- $n$-butyric acid in comparison with the control treatment. 


\section{Discussion}

Although a previous study demonstrated that supplemental feeding with epilactose did not have an impact on the plasma lipid concentration in rats fed high-sucrose diets ${ }^{(20)}$, some prebiotic oligosaccharides reportedly exhibit an ameliorative effect on diet-induced obesity and metabolic dysregulation ${ }^{(9,21,22)}$. The present study showed that epilactose effectively prevents metabolic disorders probably through the up-regulation of $U C P-1$ expression in skeletal muscles and brown adipose tissue in mice fed HF diets. Notably, our results reveal that propionic acid, which is produced in large amounts through the intestinal fermentation of epilactose, induces $U C P-1$ expression in differentiated myogenic cells.

Obesity and related diseases are the result of a complex interaction of genetic and environmental factors. Among environmental factors, fat-enriched diet and excessive energy intake are closely associated with the occurrence of these diseases, and therefore the development of novel preventive approaches has been eagerly anticipated. Supplemental feeding with epilactose for 8 weeks resulted in a significant reduction in body weight gain and visceral fat pad weight without affecting

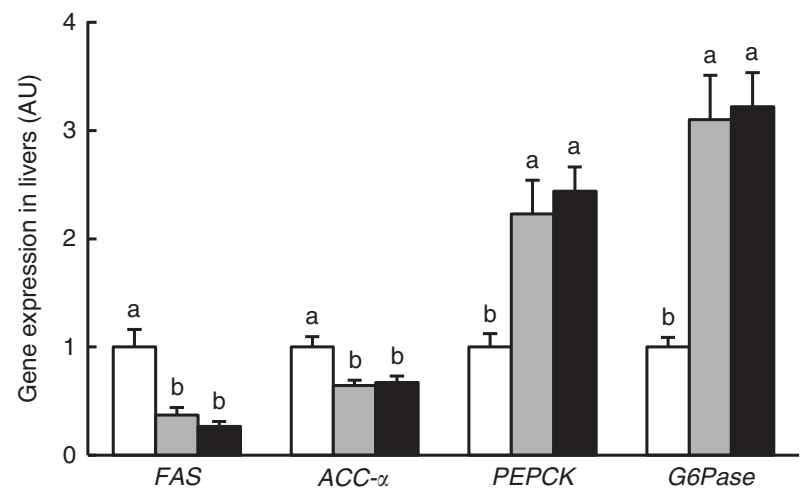

Fig. 3. Expression levels of fatty acid synthase (FAS) acetyl-CoA carboxylase- $a$ $(A C C-a)$, phosphoenolpyruvate carboxykinase 1 (PEPCK) and glucose-6phosphatase (G6Pase) in the liver of mice in Expt 2. Livers were collected at the end of experiment. AU, arbitrary units; Std, standard diet; HF, high-fat diet; Cont, control; Epi, epilactose. Values are means (n 7-8), with their standard errors represented by vertical bars. ${ }^{a, b}$ Mean values with unlike letters were significantly different $(P<0.05) . \square$, Std + Cont; $\square, \mathrm{HF}+$ Cont; $\square, \mathrm{HF}+$ Epi. food intake or faecal TAG excretion in mice fed the HF diets. The histological analysis of epididymal adipose tissues shows that feeding epilactose suppresses the adipocyte hypertrophy induced by the HF diets. White adipose tissue stores redundant energy in the form of TAG droplets during nutritional excess, and obesity is characterised by an increase in the size of adipocytes differentiated from fibroblastic pre-adipocytes in adipose tissue. These findings suggest that supplemental epilactose increases whole-body energy expenditure, resulting in lower body and fat pad weights.

Several studies have demonstrated that UCP proteins have pathophysiological roles in energy metabolism in human as well as in rodents ${ }^{(23,24)}$. Our results suggest that supplemental epilactose enhances energy expenditure through increased $U C P-1$ expression in skeletal muscles and brown adipose tissue. We focused on muscular $U C P-1$, in particular, as skeletal muscles make up approximately $40 \%$ of the total adult body weight in contrast to the relatively small contribution made by brown adipose tissue ${ }^{(25)}$. It is likely that whole-body energy expenditure could be significantly increased by the activation of muscular $U C P-1$. It has been reported that the overexpression of $U C P-1$ in the skeletal muscle of mice increases energy expenditure, resulting in decreased plasma insulin, glucose, and cholesterol levels as well as decreased adiposity ${ }^{(13,14)}$. In addition, UCP-1 expression in the muscles protects mice from HF diet-induced obesity $^{(26)}$. These findings re-inforce our hypothesis that the increases in muscular UCP-1 make a significant contribution to the epilactose-mediated prevention of obesity and metabolic dysregulation.

The finding that propionic acid, at a concentration corresponding to physiological levels in the blood of humans and rodents, stimulates $U C P-1$ expression in $\mathrm{C} 2 \mathrm{C} 12$ cells suggests that this SCFA mediates the epilactose-induced increase in $U C P-1$ in mouse muscle. It has been reported that at least two $G$ protein-coupled receptors (GPR) for SCFA, GPR41 and GPR43 are expressed in muscle cells and C2C12 cells ${ }^{(27,28)}$. Some studies have demonstrated that GPR41 and GPR43 have an important role in the regulation of energy expenditure and carbohydrate and lipid metabolisms ${ }^{(10,11)}$. UCP-1 expression is increased in $\mathrm{C} 2 \mathrm{C} 12$ cells incubated with propionic acid at $0 \cdot 1$ and $0.3 \mathrm{~mm}$, and a small, although NS, increase is observed in C2C12 cells incubated with $0.1 \mathrm{~mm}-n$-butyric acid. Functional

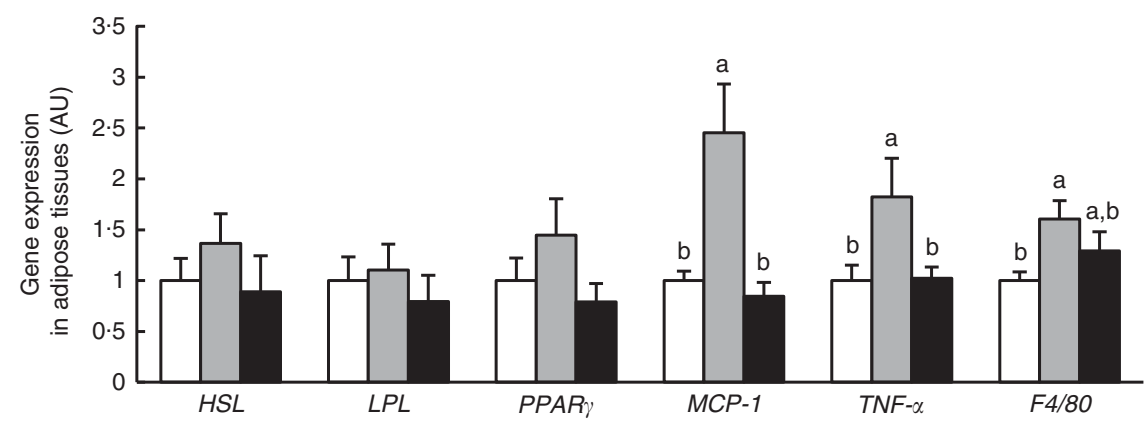

Fig. 4. Expression levels of hormone-sensitive lipase (HSL), lipoprotein lipase (LPL), $P P A R \gamma$, monocyte chemotactic protein-1 (MCP-1), TNF- $a$ and $F 4 / 80$ in the epididymal adipose tissue of mice in Expt 2. Epididymal adipose tissues were collected at the end of experiment. AU, arbitrary units; Std, standard diet; HF, high-fat diet; Cont, control; Epi, epilactose; UCP, uncoupling protein. Values are means $(n 7-8)$, with their standard errors represented by vertical bars. ${ }^{\text {,b }}$ Mean values with unlike letters were significantly different $(P<0.05) . \square$, Std + Cont; $\square$, HF + Cont; $\square$, HF + Epi. 

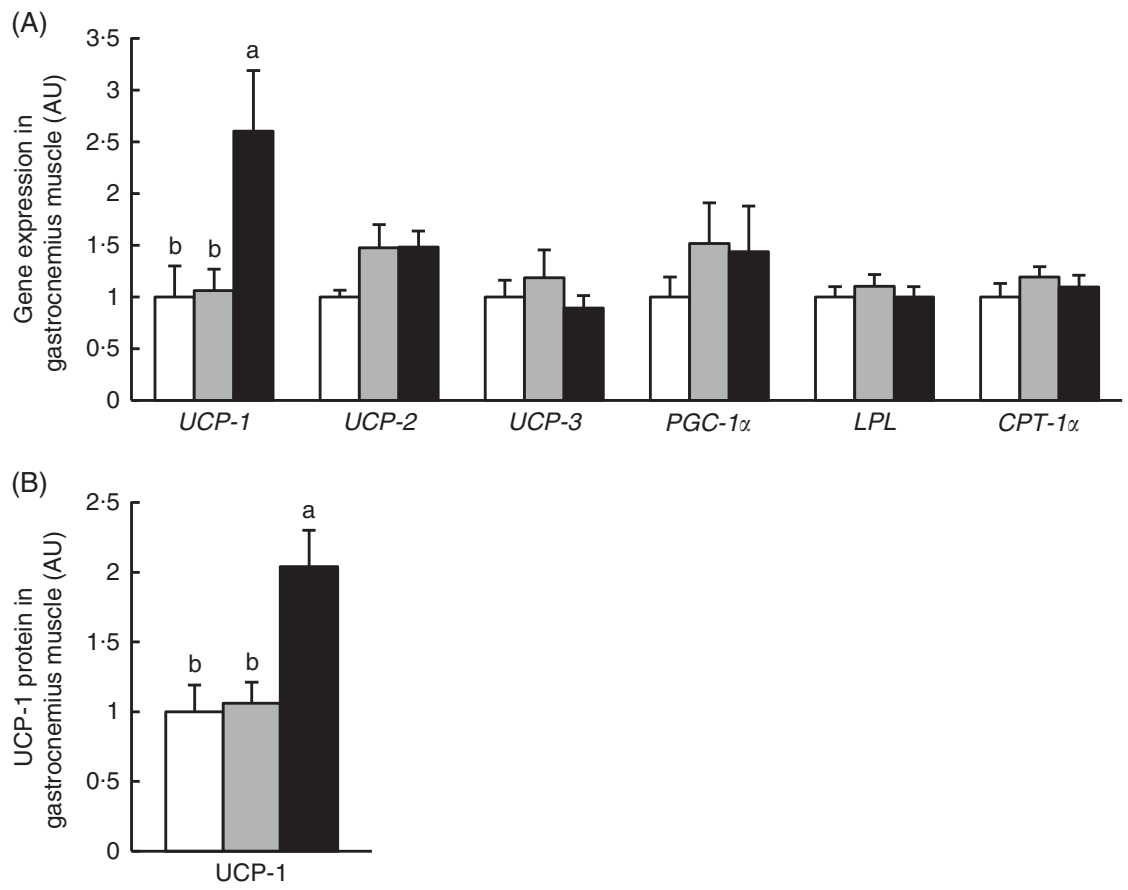

Fig. 5. Expression levels of uncoupling protein (UCP)-1, UCP-2, UCP-3, PPARy coactivator $1 a(P G C$-1a), lipoprotein lipase (LPL) and carnitine palmitoyltransferase$1 a(C P T-1 a)$ in the gastrocnemius muscle of mice in Expt 2. Gastrocnemius muscles were collected at the end of experiment. (A) mRNA expression levels of UCP-1, UCP-2, UCP-3, PGC-1a, LPL and CPT-1a in the muscle are shown. (B) The UCP-1 protein expression level is shown. AU, arbitrary units; Std, standard diet; HF, highfat diet; Cont, control; Epi, epilactose. Values are means $(n 7-8)$, with their standard errors represented by vertical bars. ${ }^{a, b}$ Mean values with unlike letters were significantly different, $P<0.05 . \square$, Std + Cont; $\square, \mathrm{HF}+$ Cont; $\square, \mathrm{HF}+$ Epi.

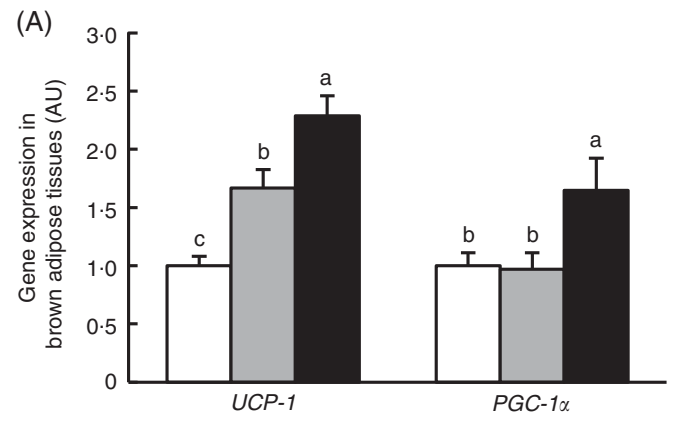

(B)

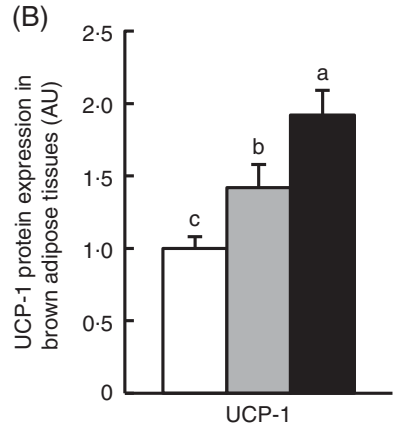

Fig. 6. Expression levels of uncoupling protein (UCP)-1 and PPARy coactivator $1 a(P G C-1 a)$ in the brown adipose tissue of mice in Expt 2. Brown adipose tissues were collected at the end of experiment. (A) mRNA expression levels of UCP-1 and PGC-1a in the brown adipose tissue are shown. (B) The UCP-1 protein expression level is shown. AU, arbitrary units; Std, standard diet; HF, high-fat diet; Cont, control; Epi, epilactose. Values are means (n 7-8), with their standard errors represented by vertical bars. ${ }^{a, b, c}$ Mean values with unlike letters were significantly different $(P<0.05) . \square, \mathrm{Std}+$ Cont; $\square, \mathrm{HF}+$ Cont; $\square, \mathrm{HF}+$ Epi. assays indicate that GPR43 is activated by acetic, propionic and $n$-butyric acids to a similar degree, whereas the rank order of potencies for GPR41 is propionic $>n$-butyric $\gg$ acetic acids ${ }^{(28)}$. According to these studies, the propionic acid-mediated increase in $U C P-1$ expression may occur via GPR41 activation. However, the underlying mechanisms for the epilactosemediated increases in $U C P-1$ expression appear to differ between skeletal muscle and brown adipose tissue, as feeding epilactose increases $P G C-1 \alpha$, a transcription regulator of $U C P-1$, in brown adipose tissue only. Further studies are required to clarify the precise mechanisms for the epilactose-mediated increase in $U C P-1$ expression.

A growing body of evidence supports the notion that obesity and metabolic disorders are characterised by a chronic state of low-grade inflammation with pro-inflammatory macrophage infiltration into white adipose tissue ${ }^{(29,30)}$. This macrophage infiltration is triggered by the release of pro-inflammatory adipokines, including $M C P-1$, from lipid-laden adipocytes. Once macrophages infiltrate into adipose tissue, they interact with adipocytes through $T N F-\alpha$ release to increase pro-inflammatory adipokine secretion and decrease anti-inflammatory adipokine secretion, leading to the progression of metabolic dysregulation such as insulin resistance and hyperlipidaemia. The inhibition of crosstalk between adipocytes and macrophages and the decrease in macrophage infiltration by feeding epilactose are confirmed by the decreased expression of $M C P-1, T N F-\alpha$ and F4/80 in adipose tissue. These results suggest that supplemental feeding with epilactose prevents macrophage infiltration into adipose tissues due to the suppression of lipid accumulation. 

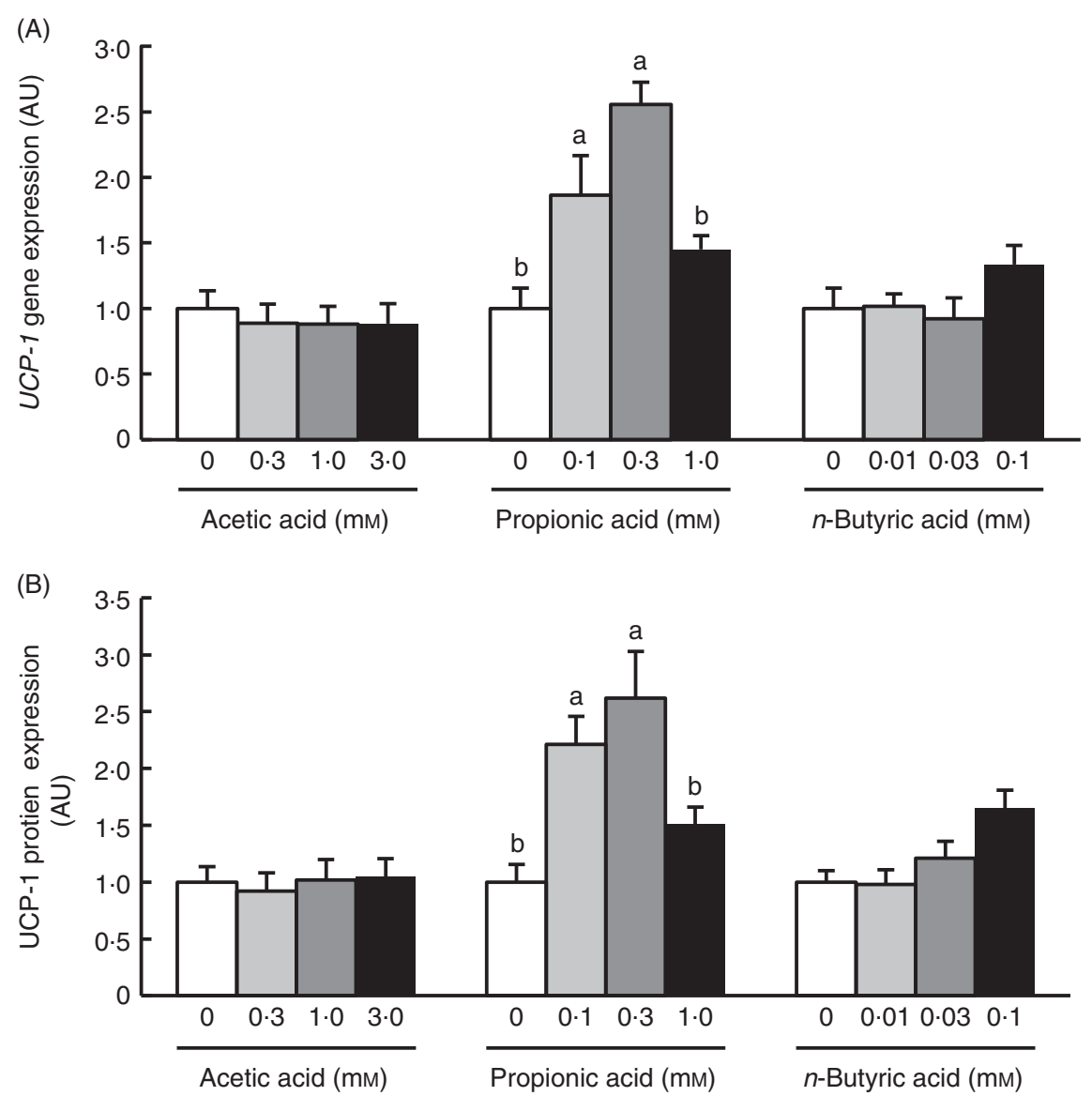

Fig. 7. Uncoupling protein (UCP)-1 expression in $\mathrm{C} 2 \mathrm{C} 12$ cells in Expt 3. Cells were collected after incubation for $24 \mathrm{~h}$ with acetate, propionate or $n$-butyrate. mRNA (A) and protein (B) expressions of UCP-1 in cells are shown. Data are representative of three independent experiments. Values are means $(n 6)$, with their standard errors represented by vertical bars. ${ }^{a, b}$ Mean values with unlike letters were significantly different $(P<0.05)$. AU, arbitrary units.

In conclusion, supplemental feeding with epilactose - a nondigestible disaccharide - effectively prevents HF diet-induced obesity and metabolic dysregulation probably through increased $U C P-1$ expression in the skeletal muscles and brown adipose tissue. Propionic acid, an intestinal bacterial metabolite, may be involved in the epilactose-mediated increase in $U C P$ - 1 expression in muscles. Although further studies for the direct evaluation of the increased thermogenesis and energy expenditure resulting from feeding epilactose are required, this non-digestible disaccharide appears to have the potential as a novel functional food for the prevention of metabolic disorders.

\section{Acknowledgements}

The present study was supported in part by JSPS KAKENHI (T. S., grant no. 25660106). JSPS had no role in the design, analysis or writing of this article.

The authors' contributions are as follows: Y. M. and T. S. designed and conducted the research and performed the statistical analysis of the data; T. O., W. S., H. M., H. Ma. and $S$. T. helped in conducting the research; and T. S. wrote the paper and had the primary responsibility for the final content. All the authors read and approved the final version of the manuscript.

The authors declare no conflicts of interest.

\section{Supplementary material}

For supplementary material/s referred to in this article, please visit http://dx.doi.org/doi:10.1017/S0007114515003505

\section{References}

1. Cataldi TR, Angelotti M \& Bufo SA (1999) Method development for the quantitative determination of lactulose in heat-treated milks by HPAEC with pulsed amperometric detection. Anal Chem 71, 4919-4925.

2. Ito S, Taguchi H, Hamada S, et al. (2008) Enzymatic properties of cellobiose 2-epimerase from Ruminococcus albus and the synthesis of rare oligosaccharides by the enzyme. Appl Microbiol Biotechnol 79, 433-441.

3. Suzuki T, Nishimukai M, Shinoki A, et al. (2010) Ingestion of epilactose, a non-digestible disaccharide, improves postgastrectomy osteopenia and anemia in rats through the promotion of intestinal calcium and iron absorption. J Agric Food Chem 58, 10787-10792.

4. Kahn SE, Hull RL \& Utzschneider KM (2006) Mechanisms linking obesity to insulin resistance and type 2 diabetes. Nature 444, 840-846.

5. Johns DJ, Lindroos AK, Jebb SA, et al. (2015) Dietary patterns, cardiometabolic risk factors, and the incidence of cardiovascular disease in severe obesity. Obesity (Silver Spring) 23, 1063-1070. 
6. Parillo M \& Riccardi G (2004) Diet composition and the risk of type 2 diabetes: epidemiological and clinical evidence. $\mathrm{BrJ}$ Nutr 92, 7-19.

7. Roberfroid M, Gibson GR, Hoyles L, et al. (2010) Prebiotic effects: metabolic and health benefits. BrJ Nutr 104, S1-63.

8. Cani PD \& Delzenne NM (2009) The role of the gut microbiota in energy metabolism and metabolic disease. Curr Pharm Des 15, 1546-1558.

9. Delzenne NM, Daubioul C, Neyrinck A, et al. (2002) Inulin and oligofructose modulate lipid metabolism in animals: review of biochemical events and future prospects. Br J Nutr 87, S255-S259.

10. Hara T, Kashihara D, Ichimura A, et al. (2014) Role of free fatty acid receptors in the regulation of energy metabolism. Biochim Biophys Acta 1841, 1292-1300.

11. Kimura I, Ozawa K, Inoue D, et al. (2013) The gut microbiota suppresses insulin-mediated fat accumulation via the shortchain fatty acid receptor GPR43. Nat Commun 4, 1829.

12. Ricquier D \& Bouillaud F (2000) The uncoupling protein homologues: UCP1, UCP2, UCP3, StUCP and AtUCP. Biochem $J 345,161-179$.

13. Li B, Nolte LA, Ju JS, et al. (2000) Skeletal muscle respiratory uncoupling prevents diet-induced obesity and insulin resistance in mice. Nat Med 6, 1115-1120.

14. Couplan E, Gelly C, Goubern M, et al. (2002) High level of uncoupling protein 1 expression in muscle of transgenic mice selectively affects muscles at rest and decreases their IIb fiber content. J Biol Chem 277, 43079-43088.

15. Reeves PG, Nielsen FH \& Fahey GC Jr (1993) AIN-93 purified diets for laboratory rodents: final report of the American Institute of Nutrition ad hoc writing committee on the reformulation of the AIN-76A rodent diet. J Nutr 123, 1939-1951.

16. Bligh EG \& Dyer WJ (1959) A rapid method of total lipid extraction and purification. Can J Biochem Physiol 37, 911-917.

17. Laemmli UK (1970) Cleavage of structural proteins during the assembly of the head of bacteriophage T4. Nature $\mathbf{2 2 7}$, 680-685.

18. Okazaki Y, Ohshima N, Yoshizawa I, et al. (2010) A novel glycerophosphodiester phosphodiesterase, GDE5, controls skeletal muscle development via a non-enzymatic mechanism. J Biol Chem 285, 27652-27663.

19. Jakobsdottir G, Jadert C, Holm L, et al. (2013) Propionic and butyric acids, formed in the caecum of rats fed highly fermentable dietary fibre, are reflected in portal and aortic serum. Br J Nutr 110, 1565-1572.

20. Nishimukai M, Watanabe J, Taguchi H, et al. (2008) Effects of epilactose on calcium absorption and serum lipid metabolism in rats. I Agric Food Chem 56, 10340-10345.

21. Cani PD, Possemiers S, Van de Wiele T, et al. (2009) Changes in gut microbiota control inflammation in obese mice through a mechanism involving GLP-2-driven improvement of gut permeability. Gut 58, 1091-1103.

22. Xie S, Zhu J, Zhang Y, et al. (2012) Effects of soya oligosaccharides and soya oligopeptides on lipid metabolism in hyperlipidaemic rats. Br J Nutr 108, 603-610.

23. Cypess AM, Lehman S, Williams G, et al. (2009) Identification and importance of brown adipose tissue in adult humans. $N$ Engl J Med 360, 1509-1517.

24. Virtanen KA, Lidell ME, Orava J, et al. (2009) Functional brown adipose tissue in healthy adults. $N$ Engl J Med 360, 1518-1525.

25. Harper ME, Green K \& Brand MD (2008) The efficiency of cellular energy transduction and its implications for obesity. Annu Rev Nutr 28, 13-33.

26. Katterle Y, Keipert S, Hof J, et al. (2008) Dissociation of obesity and insulin resistance in transgenic mice with skeletal muscle expression of uncoupling protein 1. Physiol Genomics 32, 352-359.

27. Nilsson NE, Kotarsky K, Owman C, et al. (2003) Identification of a free fatty acid receptor, FFA2R, expressed on leukocytes and activated by short-chain fatty acids. Biochem Biophys Res Commun 303, 1047-1052.

28. Suzuki T, Elias BC, Seth A, et al. (2009) PKC eta regulates occludin phosphorylation and epithelial tight junction integrity. Proc Natl Acad Sci USA 106, 61-66.

29. Bai Y \& Sun Q (2015) Macrophage recruitment in obese adipose tissue. Obes Rev 16, 127-136.

30. Exley MA, Hand L, O'Shea D, et al. (2014) Interplay between the immune system and adipose tissue in obesity. J Endocrinol 223, R41-R48. 